\title{
Media Komunikasi Visual Sebagai Infografis Di Kecamatan Jayanti Kabupaten Tangerang
}

\author{
Karunia Suci Lestari ${ }^{1}$, Andykha Purnawan Abidin ${ }^{2}$, Chika Febiola ${ }^{3}$ \\ ${ }^{1,2,3}$ Program Studi Teknik Informatika, Fakultas Sains dan Teknologi, Universitas Raharja \\ Email : *1 $\underline{\text { suci@ raharja.info }},{ }^{2}$ andykha@ raharja.info, ${ }^{3}$ chika.febiola@ raharja.info
}

\begin{abstract}
Abstrak
Di masa pandemic covid-19 ini yang terjadi di Indonesia bahkan seluruh dunia membuat aktivitas yang biasa dilakukan menjadi terbatas dan memaksa kita untuk diam dirumah saja. Media informasi mengenai protocol kesehatan dibutuhkan dimana-mana untuk mengingatkan masyarakat betapa pentingnya protocol kesehatan guna pencegahan penyebaran virus ini. Kecamatan Jayanti dalam menyampaikan informasi masih kurang efisien dan belum tersampaikan secara merata dan meluas, informasi yang disampaikan belum sesuai dengan informasi yang berkembang saat ini seperti informasi tentang protocol kesehatan untuk mencegah penyebaran virus Covid-19, serta bertepatan juga dengan acara HUT Republik Indonesia yang ke-75. Agar dapat menyelesaikan permasalahan ini dibutuhkan media infografis yang baik dan akurat maka dibuatlah media cetak seperti: spanduk wajib memakai masker saat keluar rumah, spanduk pencegahan Covid-19, baliho HUT RI, serta baliho Bantuan Sosial Tunai (BST). Metode penelitiannya yaitu: mengumpulkan data, observasi dan menganalisa perancangan media menggunakan software CorellDraw X5. Dengan adanya media infografis berupa media cetak diharapkan dapat membantu instansi dalam memberikan informasi kepada masyarakat sesuai informasi yang berkembang saat ini.
\end{abstract}

Kata Kunci - Media, Infografis, Desain, Spanduk

\begin{abstract}
During the covid-19 pandemic, indonesia and even the rest of the world make the usual activities limited and force us to stay at home. Media information about health protocols is needed everywhere to remind the public how important health protocols are to prevent the spread of this virus. Jayanti sub-district in conveying information is still less efficient and has not been conveyed evenly and widely, the information submitted is not in accordance with the information that is developing today such as information about health protocols to prevent the spread of the Covid-19 virus, as well as coincide with the 75th Anniversary of the Republic of Indonesia. In order to solve this problem, a good and accurate infographic media is needed, print media such as: banners must wear masks when leaving the house, Covid-19 prevention banners, Indonesian Anniversary billboards, and Cash Social Assistance (BST) billboards. The research method is: collect data, observe and analyze media design using CorellDraw X5 software. With the infographic media in the form of print media is expected to help agencies in providing information to the public in accordance with the information that is developing today.
\end{abstract}

Keywords - Media, Infographics, Design, Banners

\section{PENDAHULUAN}

Masa Pandemic Covid-19 membuat sebagian kegiatan yang biasa dilakukan menjadi terbatas dan membuat kita harus berdiam \#dirumahaja. Bahkan kegiatan apapun sebagian diminta untuk dikerjakan dirumah, selain itu media infografis tentang protocol kesehatan dan berbagai pencegahan penyebaran virus covid-19 sangat dibutuhkan. Ini membuat media infografis sangat dibutuhkan dimana-mana, tak peduli instansi milik Negara maupun swasta. Sehingga media infografis dalam bentuk apapun seperti media cetak harus selalu up to date, 
media komunikasi ini sangat dibutuhkan untuk mengajak khususnya masyarakat luas untuk memenuhi protocol kesehatan yang tentunya sangat penting bagi diri sendiri maupun masyarakat luas untuk pencegahan penyebaran virus Covid-19 yang sangat membahayakan. Media cetak adalah saluran komunikasi di mana pesan tertulis serta dalam bentuk gambar seperti poster dan papan iklan dibawa dalam bentuk cetak. Informasi adalah data atau objek yang ditentukan sebelumnya, sehingga dapat diklasifikasikan dengan benar yang mempunyai arti dan bisa untuk mengambil keputusan ${ }^{[1]}$. Media komunikasi visual dalam bentuk cetak seperti: spanduk, baliho, poster terpasang di setiap sudut lingkungan rumah, kantor, tempat ibadah, pasar, swalayan bertebaran dijalan guna menginggatkan kepada masyarakat betapa pentingnya protocol kesehatan. Desain komunikasi visual adalah elemen visual untuk penggambaran proses pengolahan media dalam berkomunikasi mengenai pengungkapan ide kreatif atau penyampaian informasi yang bisa terbaca atau terlihat ${ }^{[2]}$. Media cetak ini mudah dilihat oleh masyarakat langsung tanpa perlu akses internet sehingga memudahkan audience mengetahui informasi apa yang disampaikan.

Media komunikasi visual adalah sarana penyampaian pesan serta informasi menggunakan desain grafis yang memiliki unsur tipografi, ilustrasi/ gambar yang dikemas menggunakan layout agar terlihat menarik oleh audience serta pesan dan informasi yang ingin disampaikan tersampaikan. Sehingga media komunikasi visual sangatlah cocok sebagia media infografis dalam penyampaian pesan dan informasi kepada masyarakat luas.

Kantor Kecamatan Jayanti yang bertempat di Desa Jayanti, Kec. Jayanti, Kab. Tangerang. Kantor Kecamatan Jayanti merupakan wilayah kerja Camat sebagai perangkat daerah Kabupaten Tangerang yang bergerak di bidang Pemerintahan Daerah, dan menjadi inti dalam sarana dan prasana Masyarakat setempat. Kantor kecamatan Jayanti memiliki tanggung jawab untuk menyampaikan informasi kepada masyarakat melalui media cetak seperti spanduk, poster, dan baliho. Permasalahan yang di hadapi Kecamatan Jayanti dalam menyampaikan informasi masih kurang efisien dan belum tersampaikan secara merata dan meluas, informasi yang disampaikan belum sesuai dengan informasi yang berkembang saat ini seperti informasi tentang protocol kesehatan untuk mencegah penyebaran virus Covid-19, serta bertepatan juga dengan acara HUT Republik Indonesia yang ke-75. Sehingga dibutuhkan media infografis dalam bentuk media komunikasi visual untuk mengikuti perkembangan informasi yang ada di masyarakat dan sebagai bentuk kepedulian Kecamatan Jayanti yang bekerjasama dengan Kepala Polsek Cisoka, Daranmil 13/ Cisoka dan beberapa Kepala Desa di Kecamatan Jayanti untuk mengayomi masyarakatnya agar tetap patuh dalam protocol kesehatan. Selain itu, sebagai informasi mengenalkan kepada masyarakat Kecamatan Jayanti mengenai Kepala Desa masing-masing daerah Kelurahan/ Desa yang ada di Kecamatan Jayanti serta menginformasikan ke masyarakat di Kecamatan Jayanti tentang penyerahan Bantuan Sosial Tunai (BST) Tahap 3 di Kelurahan/ Desa dalam bentuk spanduk ataupun baliho. Spanduk adalah bentuk iklan yang digunakan untuk menarik perhatian. Ada berbagai ukuran yang digunakan, mulai dari sangat kecil, lebar, memanjang, hingga melintang ${ }^{[3]}$. Warna yang digunakan identik warna ungu karena warna ungu diartikan sebagai perisai merepresentasikan kemewahan, kebijaksanaan, kekuatan serta ambisi dan warna emas yang dikenal sebagai representasi warna juara, warna pemenang. Serta menggunakan dasar warna merah karena bertepatan dengan hari kemerdekaan Republik Indonesia yang mencerminkan keberanian bangsa kita.

Dengan adanya desain spanduk ini bisa di publikasikan di setiap daerah dan dapat di yakini bisa melengkapi kekurangan yang di miliki Kecamatan Jayanti dalam menyampaikan dan memberikan informasi untuk tetap patuh dalam protocol kesehatan serta memeriahkan acara HUT Republik Indonesia yang ke-75. Media komunikasi visual ini dibuat menggunakan software CorelDraw X5. CorelDraw adalah aplikasi pemrosesan grafis berbasis garis dan vektor, di mana elemen dasarnya adalah garis ${ }^{[4]}$.

Melalui media komunikasi visual dalam bentuk spanduk dan baliho ini masyarakat dapat mengetaahui informasi mengenai protocol kesehatan serta acara yang diadakan saat HUT Republik Indonesia di Kecamatan Jayanti. Spanduk dan baliho mengenai protocol kesehatan akan dipasang di beberapa Keluarahan/ Desa di Kecamatan Jayanti baik masyarakat di 
lingkungan Keluarahan/ Desa disana maupun masyarakat luas yang melewati Kelurahan/Desa tersebut dapat lebih mematuhi protocol kesehatan untuk mencegah penyebaran Covid-19. Dan untuk spanduk/ baliho tema HUT Republik Indonesia akan dipasang di sekitar kantor Kecamatan Jayanti.

\section{METODE PENELITIAN}

Metode yang digunakan untuk penelitian ini yaitu : (1) Metode pengumpulan data (a) observasi melakukan penelitian secara langsung pada Kecamatan Jayanti (b) Studi pustaka, untuk mencari teori-teori yang bersangkutan pada penelitian yang kita buat (c) wawancara dengan melakukan tanya jawab pada stakeholder Kecamatan Jayanti. (2) Metode analisa dengan menggunakan perancangan software CorellDraw x5. (3) Konsep desain melalui layout kasar, komprehensif dan final artwork.

\section{LITERATURE REVIEW}

Berikut adalah literature review yang terkait dengan topik penelitian :

Penelitian yang di lakukan oleh Ahmad $(2020)^{[5]}$. Dengan judul Spanduk dan Stiker sebagai Media Komunikasi untuk Melaporkan Peristiwa Kependudukan. Hal itu bertujuan untuk mengetahui perbedaan warga yang melaporkan insiden warga yang tinggal di desa menggunakan spanduk sebagai media komunikasi dengan warga yang tinggal di desa yang menggunakan stiker sebagai media komunikasi.

Penelitian yang di lakukan oleh Sunarya, dkk $(2018)^{[6]}$. Dengan judul Desain Komunikasi Visual Sebagai Media Informasi Pada Ditjen APTIKA Kementrian Komunikasi dan Informatika Jakarta. Bertujuan untuk menghasilkan desain dalam bentuk komunikasi visual seperti flyer, brosur, cover buku, dan logo yang menjadi informasi penting.

Penelitian yang di lakukan oleh Raharjo dan Joni Dwi Pribadi (2017) ${ }^{[7]}$.Dengan judul Desain spanduk menggunakan CorelDraw sebagai media promosi untuk meningkat kan citra pada SMP An-Nur Balulawang Malang. Bertujuan untuk pengembangan media promosi pada SMP An-Nur dengan cara membuat desain spanduk dengan informasi yang lebih lengkap mengenai SMP An-Nur Bululawang Malang.

Penelitian yang di lakukan oleh Maulani, ddk $(2017)^{[8]}$.Dengan judul Desain Media Komunikasi Visual Berbentuk Tabloid Sebagai Sarana Promosi SMK Mandiri 2. Bertujuan Menghasilkan desain dapat menunjang kegiatan promosi pada SMK Mandiri 2, sehingga masyarakat dengan mudah mengenal sekolah SMK Mandiri 2.

\section{HASIL DAN PEMBAHASAN}

\subsection{Konsep Perancangan}

Konsep perancangan media komunikasi visual memiliki beberapa perancangan yaitu :

\subsubsection{Perancangan Media}

Untuk mempermudah masyarakat sekitar melalui adanya desain media cetak sebagai penunjang informasi kepada seluruh masyarakat khususnya daerah jayanti.Berbentuk desain komunikasi visual yang di terapkan sebagai media cetak dan di implementasikan kedalam desain spanduk, baliho dan poster yang di dalam nya terdapat visualisasi logo, desain dan typography yang sesuai dengan apa yang di minta oleh stakeholder.

\subsubsection{Perancangan Pesan (Konsep Kreatif)}

Dalam pembuatan penelitian ini di implementasikan kedalam media cetak berupa informasi yang di peroleh dari Kecamatan Jayanti Kabupaten Tangerang dengan tema 
HUT RI dan Covid-19 yang diterapkan pada media spanduk sebagai bahan informasi untuk masyarakat sekitar.

\subsubsection{Perancangan Visual}

Untuk membuat desain di perlukan ide kreatif, nuansa baru serta bentuk visual agar dapat di buat secara tegas dan jelas adanya campuran unsur warna yang sesuai dengan yang diminta oleh Kecamatan Jayanti Kabupaten Tangerang. Ada beberapa desain yang di kombinasikan dengan warna-warna yang cerah dan gelap, logo, typography. Sehingga informasi visual dapat tersampaikan kepada masyarakat.

\subsection{Tujuan Kreatif Desain Media Komunikasi Visual}

Tujuan kreatif terbuatnya desain media cetak pada Kecamatan Jayanti Kabupaten Tangerang ialah untuk memberikan informasi secara jelas dan tegas melalui media komunikasi visual yang dibuat dengan warna khas daerah serta konten yang mudah di terima oleh masyarakat.

\subsection{Layout Kasar}

Layout Kasar adalah aplikasi desain media yang nantinya akan digunakan dalam desain disertai dengan referensi standardisasi pada desain yang akan dibuat, umumnya dibuat dalam tampilan hitam dan putih, dibuat dengan coretan menggunakan pensil, pena gambar ${ }^{[8]}$. Layout kasar diperlukan sebagai referensi saat memproses desain menggunakan aplikasi komputer.

Berikut adalah gambar layout kasar media komunikasi visual berupa media cetak pada Kecamatan Jayanti Kabupaten Tangerang :

- Spanduk HUT RI (Camat, Danramil, Kapolsek) dan Spanduk Penyerahan Bantuan Sosial Tunai
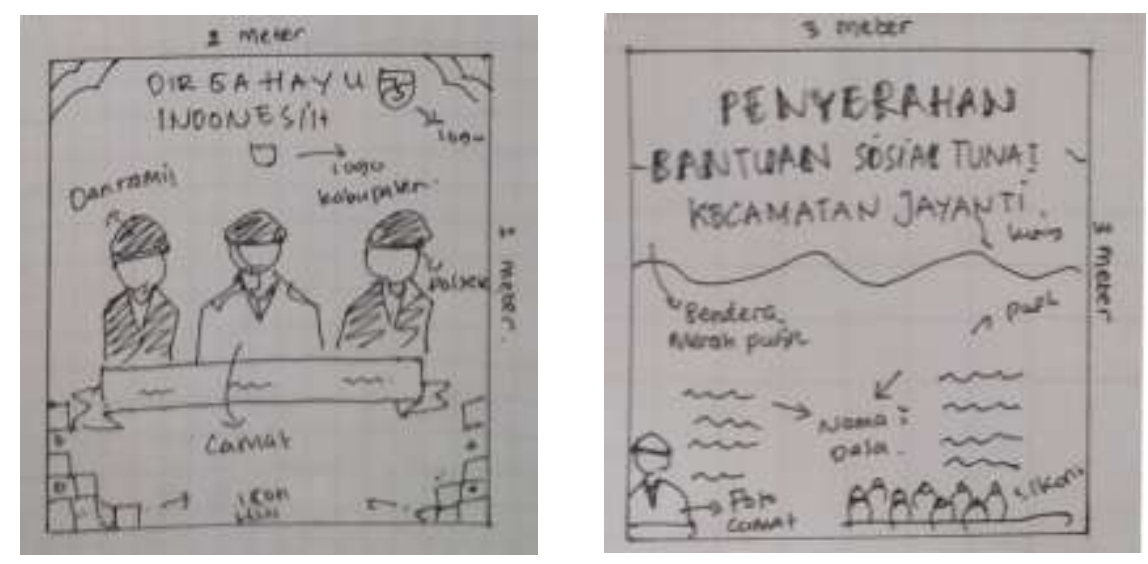

Gambar 1 dan 2 layout kasar pada spanduk hut ri dan bantuan sosial tunai.

Pada gambar 1 spanduk hut ri berukuran $2 \times 2$ meter, didalam nya ada gambar camat, danramil dan kapolsek untuk memberi informasi pada masyarakat. Pada gambar 2 spanduk bantuan sosial tunai berukuran $3 \times 3$ meter, pada gambar tersebut berupa informasi lebih lanjut daerah mana saja yang mendapatkan BST tersebut. 
- Baliho Selamat hari jadi dan spanduk HUT RI ( Camat dan 8 Kades)
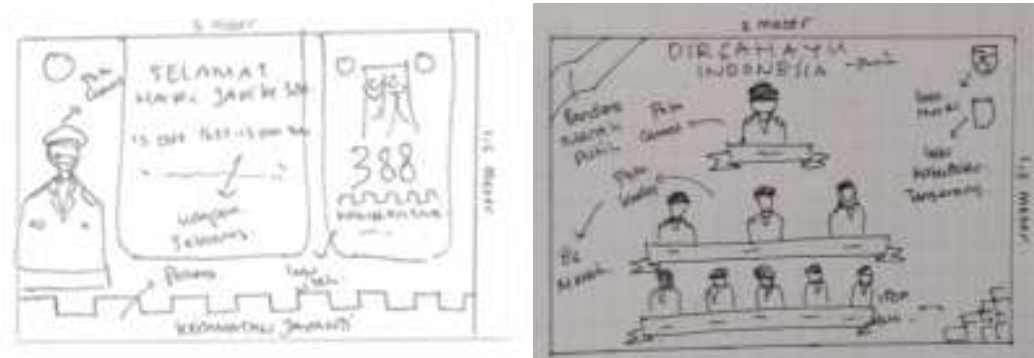

Gambar 3 dan 4 layout kasar pada spanduk HUT Kab. Tangerang dan spanduk HUT RI (camat dan 8 kades).

Pada gambar 3 baliho hari jadi berukuran $3 \times 1,5$ meter, di dalam nya terdapat foto camat logo kabupaten tangerang dan ucapan untuk melawan covid-19. Gambar 4 spanduk camat dan 8 kepala desa berukuran $2 \times 1,5$ meter, terdapat foto camat dan perwakilan delapan kepala desa.

- Spanduk Himbauan Ayo Pakai Masker!

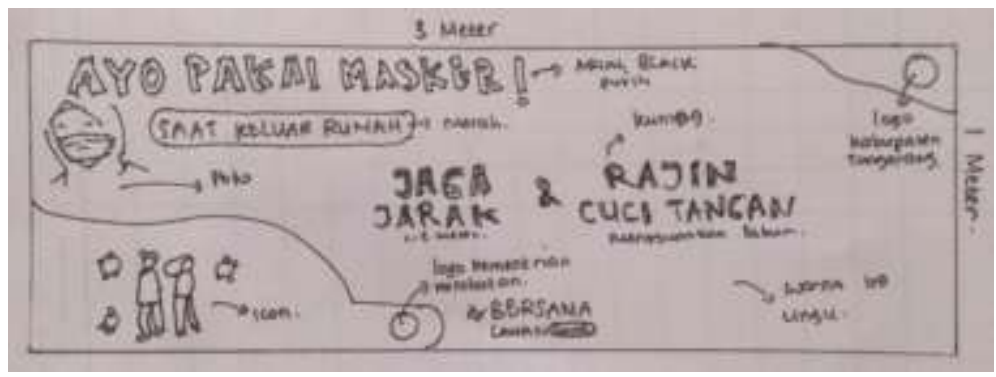

Gambar 5. layout kasar pada spanduk himbauan Ayo pakai masker!

Pada gambar 5 spanduk himbauan berukuran $3 \times 1$ meter, terdapat tulisan untuk peringatan kepada seluruh masyarakat agar selalu menggunakan masker, jaga jarak dan tidak lupa untuk mencuci tangan.

- $\quad$ Spanduk Pencegahan Virus Covid-19

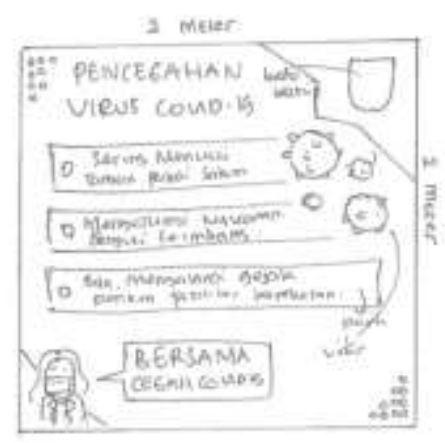

Gambar 6. layout kasar pada spanduk pencegahan virus Covid-19

Pada gambar 6 spanduk pencegahan berukuran $2 \times 2$ meter, didalamnya terdapat mengajak masyarakat untuk melakukan pencegahan agar terhindar dari virus Covid19. 


\subsection{Layout Komprehensif}

Layout Komprehensif adalah proses desain yang telah memasuki tahap pewarnaan, tetapi tahap ini belum selesai sepenuhnya, karena masih harus menjalani proses revisi ${ }^{[8]}$. Desain dirancang pada layout komprehensif ini menggunakan aplikasi penunjang desain yaitu Corel Draw X5. Berikut adalah layout komprehensif yang dibuat, dengan menggunakan font Arial Black, Cocogoose, Century Gothic, Helvetica, Blackadder ITC. Serta warna yang digunakan untuk desain ini menggunakan warna merah, putih, kuning, abu-abu, dan ungu.
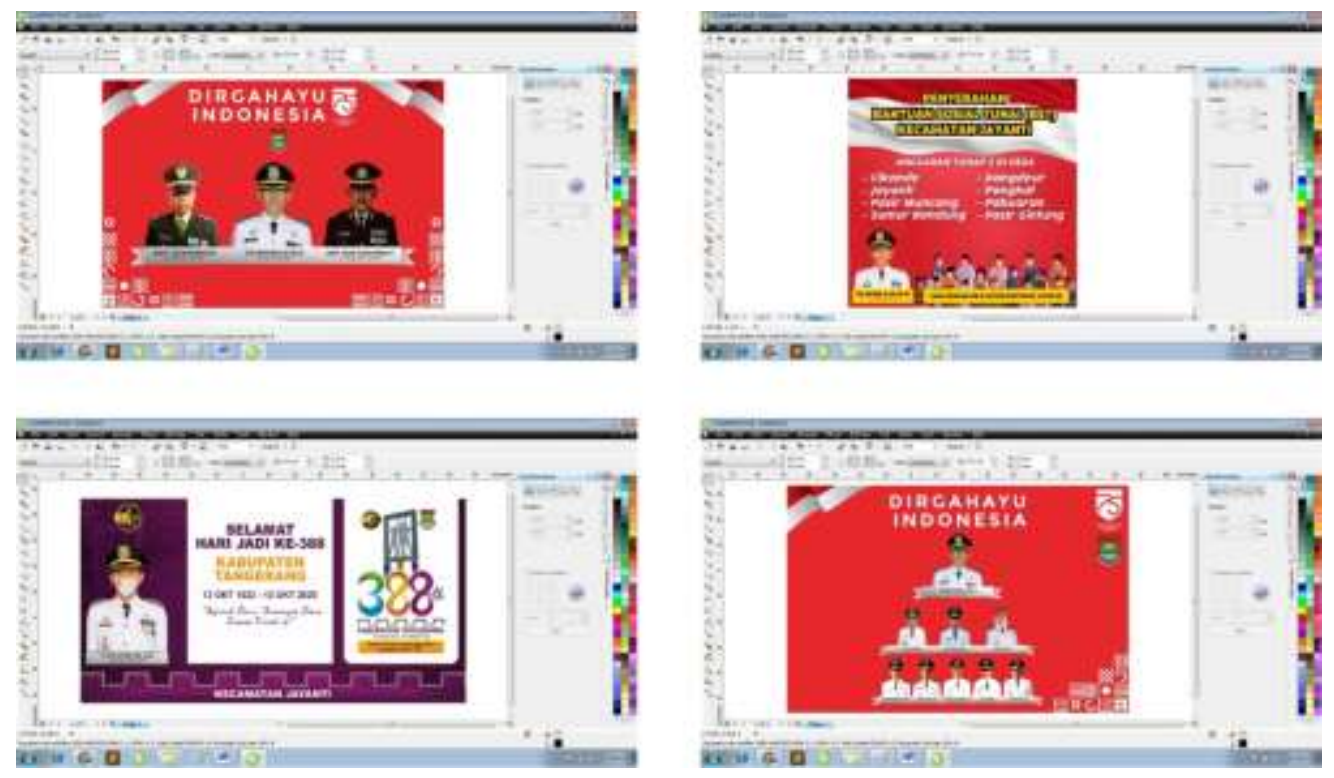

Gambar 7. layout Komprehensif pada desain spanduk sebagai penyampaian informasi mengenai HUT RI dan Kabupaten.

Pada gambar 7 merupakan spanduk yang ditunjukan sebagai informasi sekaligus dokumenter pada acara HUT RI dan HUT Kab. Tangerang.
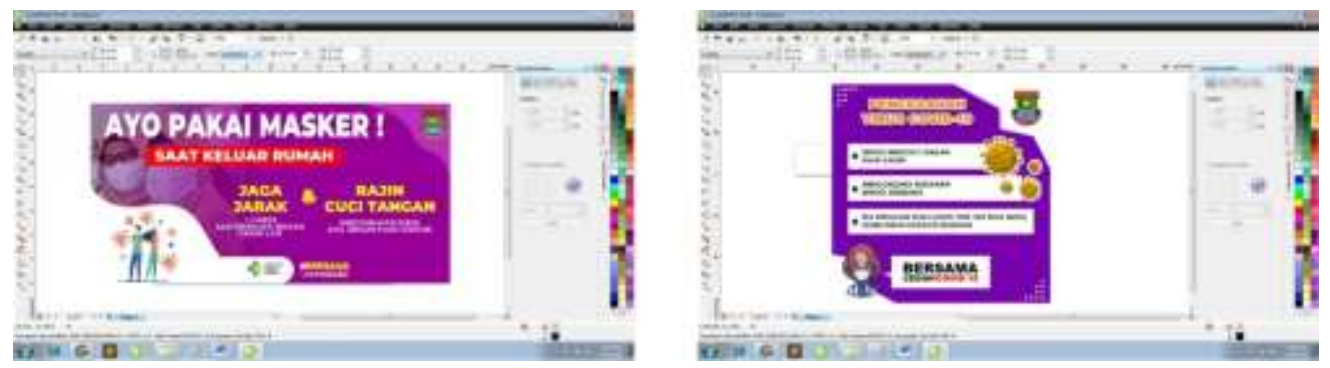

Gambar 8. layout Komprehensif pada desain spanduk sebagai penyampaian informasi mengenai Himbauan Covid-19.

Pada gambar 8 merupakan spanduk yang digunakan sebagai informasi serta himbauan untuk masyarakat agar selalu menjaga dan melaksanakn protokol kesehatan.

\subsection{Final Artwork}

Final Artwork adalah hasil akhir dari tata letak komprehensif yang telah ditingkatkan, di mana tahap ini adalah hasil akhir atau finishing yang kemudian dapat digunakan sebagai referensi selama proses produksi. Final Artwork adalah istilah untuk 
file desain akhir yang siap dicetak. Ada beberapa poin penting yang harus diperhatikan dalam menyiapkan karya seni akhir untuk menghindari kesalahan selama pencetakan yang mungkin menyebabkan hasil produksi yang tidak memuaskan. Poin penting final artwork antara lain: Bleed, Convert Font, Resolusi, Mode Warna, Crop Mark, ukuran Artwork dan Image link ${ }^{[8]}$. Berikut adalah Final Artwork yang merupakan tahap akhir dari perancangan Desain media informasi berupa spanduk :

- Spanduk HUT RI

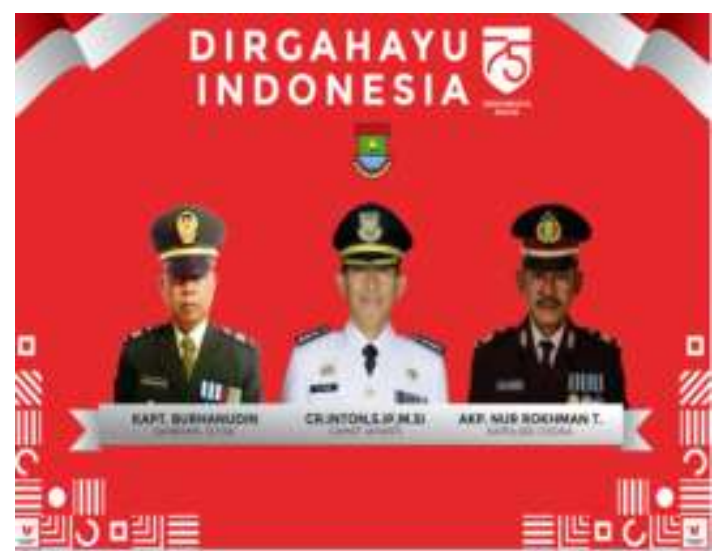

Gambar 9. Desain spanduk sebagai penyampaian informasi mengenai HUT RI dan Kabupaten.

Pada gambar 9 merupakan spanduk berukuran $2 \times 2$ meter dengan menampilkan foto Camat, Danramil dan Kapolsek Kec. Jayanti.

- Spanduk Bantuan Sosial Tunai (ST)

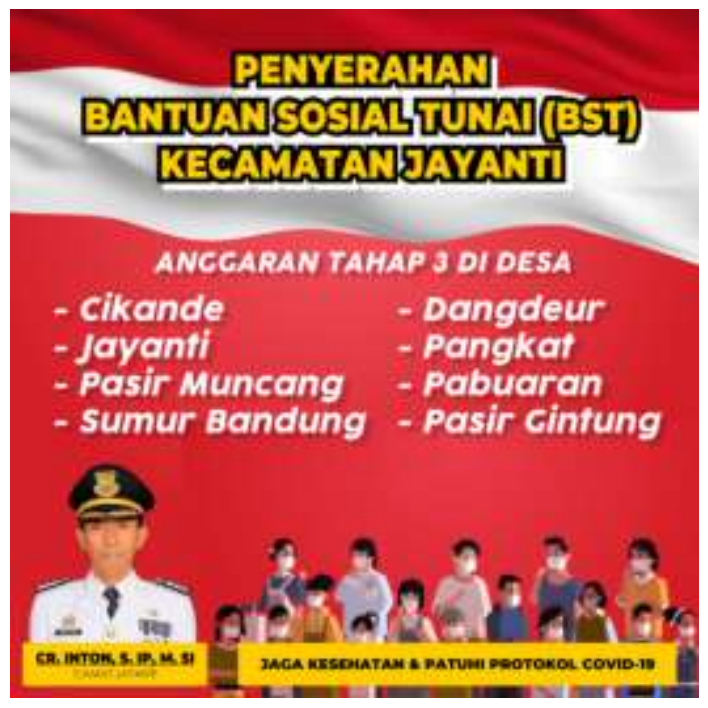

Gambar 10. Spanduk Bantuan Sosial Tunai (BST)

Pada gambar 10 ini merupakan daftar desa-desa yang berhak mendapatkan Bantuan sosial tunai selama masa pandemic dengan spanduk yang berukuran $3 \times 3$ meter yang di lengkapi dengan foto Camat Jayanti. 
- Spanduk Hut Kab. Tangerang

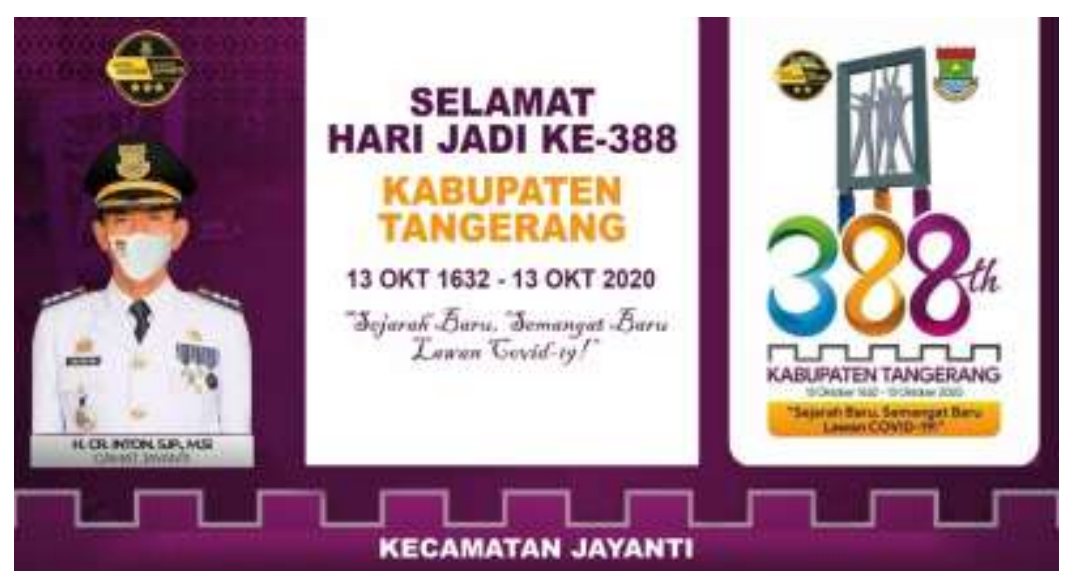

Gambar 11. Spanduk HUT Kab. Tangerang

Pada gambar 11 ini merupakan spanduk yang berisi ucapan selamat hari jadi perwakilan dari kecamatan jayanti kepada kabupaten tangerang sebagai bentuk apresiasi dan dukungan kepada peerintahan pusat daerah.

- Spanduk Hut RI (Camat Dan Kades)

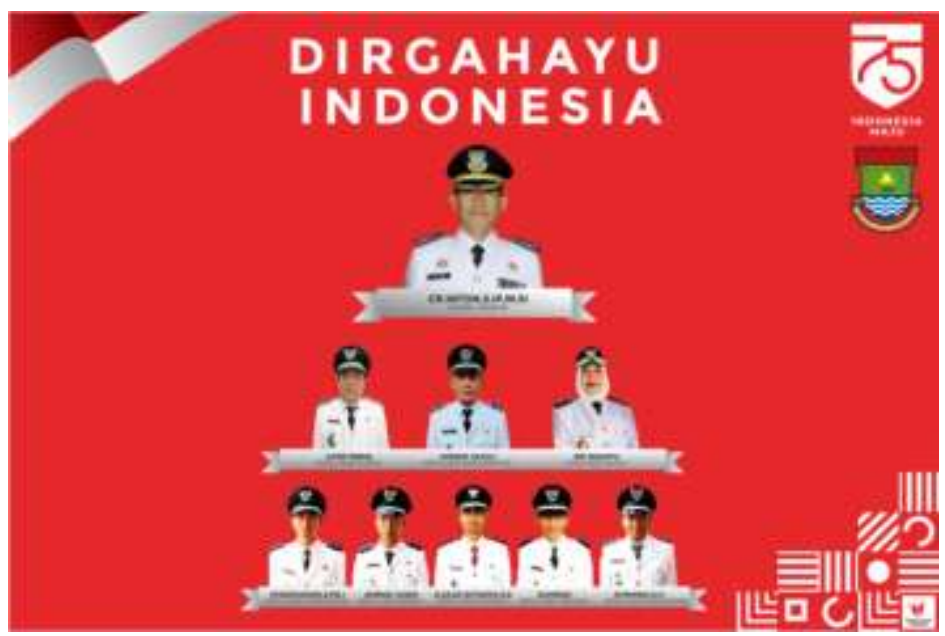

Gambar 12. Spanduk HUT RI (Camat dan Kades)

Pada gambar 12 adalah spanduk peringatan HUT RI dengan menampilkan camat dan seluruh Kepala Desa yang ada di kecamatan Jayanti dengan tema merah putih sebagai warna kesatuan. 
- Spanduk Himbauan Ayo Pakai Masker!

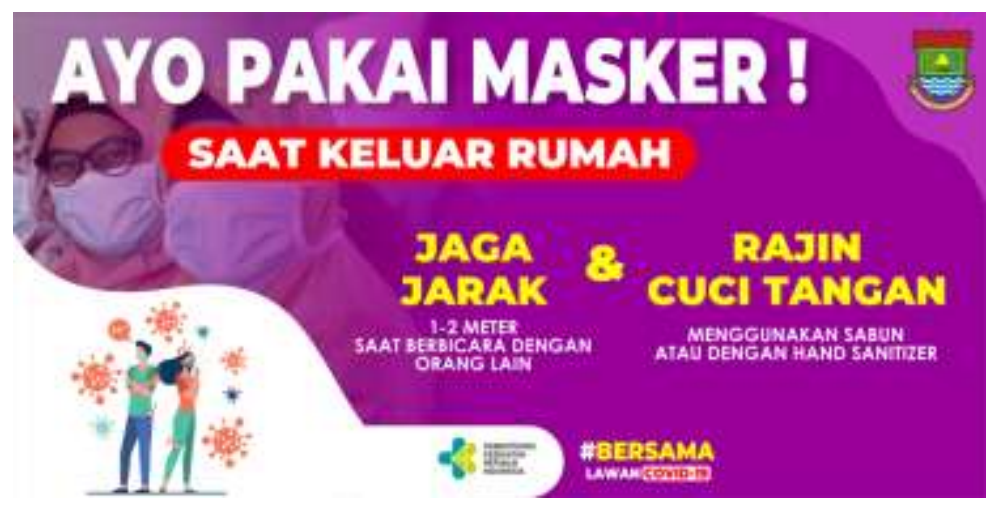

Gambar 13. Spanduk Himbauan Ayo Pakai Masker!

Pada gambar 13 merupakan spanduk himbauan kepada masyarakat agar selalu menjalankan 3M yaitu memakai masker, menjaga jarak dan selalu mencuci tangan menggunakan sabun.

- Spanduk Pencegahan Virus Covid-19

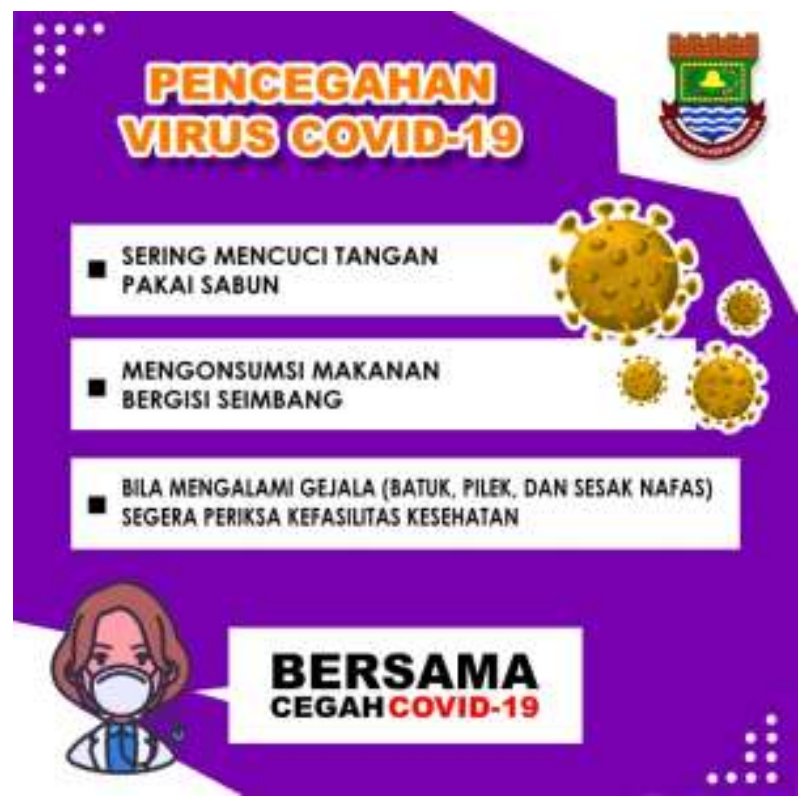

Gambar 14. Spanduk Pencegahan Virus Covid-19

Pada gambar 14 diatas merupakan spanduk sebagai bentuk kepedulian kepada masyarakat agar selalu menjaga kesehatan agar terhindar dari virus Covid-19 dan mengarahkan masyarakat apabila mengalami gejala.

\section{KESIMPULAN}

Komunikasi visual sangat penting di era sekarang ini khusus nya media cetak, dengan menyampaikan informasi melalui media tersebut mempermudah masyarakat Kecamatan Jayanti untuk mendapatkan informasi apa saja yang ada di dalamnya.Untuk membuat desain media cetak di perlukan ide kreatif dan bentuk visual agar dapat di buat secara tegas, jelas dan lebih 
efektif adanya campuran unsur warna yang sesuai dengan yang diminta oleh Kecamatan Jayanti Kabupaten Tangerang. Ada beberapa desain yang di kombinasikan dengan warna-warna yang cerah dan gelap, logo, typography. Sehingga informasi visual dapat tersampaikan kepada masyarakat beberapa hasil informasi media cetak dengan tema HUT RI, Covid-19, informasi untuk masyarakat di daerah mana saja yang dapat bantuan sosial tunai. Sehingga tujuan adanya informasi ini dapat memberikan informasi yang bermanfaat sehingga tugas Kecamatan Jayanti dapat tersampaikan kepada mesyarakat.

\section{SARAN}

Adapun saran yang dapat diberikan untuk Kantor Kecamatan Jayanti agar lebih di perhatikan lagi untuk memberikan informasi kepada masyarakat bagian design mempunyai standar media informasi untuk dapat menyampaikan kepada masyarakat, agar dapat mengetahui informasi di Kecamatan Jayanti. Serta informasi yang diberikan agar dapat mengikuti perkembangan informasi saat ini. Diharapkan kepada Kecamatan Jayanti agar lebih sering mengupdate informasi untuk masyarakat dengan media spanduk karna lebih efisien dan lebih mudah di terima.

\section{DAFTAR PUSTAKA}

[1] Supriyanti, Dedeh. Wahyu Hidayat dan Rekha Apriyana. 2019. Paket Wisata Pendakian Gunung Berbasis Web Pada PT. Seven Mountain Adventure Dengan Menggunakan PHP dan MYSQL. Tangerang : STMIK Raharja. Journal ICIT. ISSN: 2356-5195. Online ISSN: 2654 - 8704. Vol.5, No.1 : 31.

[2] Desrianti, Dewi Immaniar, Anita B Wandayana dan Asih Sumaryani. 2013. Perancangan Media Katalog Sebagai Penunjang Informasi dan Promosi Pada CV. Zero Store. Tangerang : STMIK Raharja. Journal ICIT. ISSN: 1978-8282. Vol. 7 No.2 : 288-290.

[3] Hasri, Mustiar dan Evawani Elysa Lubis. 2017. Strategi Komunikasi Pemasaran Terpadu (Integrated Marketing Communication (IMC)) Yang Diterapkan Oleh Re Caffe Platinum Pekanbaru Dalam Meningkatkan Pelanggan. Riau : Universitas Riau. Jurnal Online Mahasiswa Fakultas Ilmu Sosial dan Ilmu Politik Universitas Riau. e-ISSN: 2355-6919. Vol.4, No. 2 : 3-4.

[4] Afriansyah, Aidil. 2018. Rancang Bangun Media Pembelajaran CorelDraw berbasis Multimedia. Palembang: Politeknik Sekayu. Jurnal TIPS : Jurnal Teknologi Informasi dan Komputer Politeknik Sekayu. ISSN-E : 2654-5071. Vol. VIII, No.1: 38

[5] Ahmad, Irdam 2020. Spanduk Dan Stiker Sebagai Media Komunikasi Untuk Melaporkan Peristiwa Kependudukan. Jakarta Selatan : Sekolah Tinggi Ekonomi Dan Pariwisata Indonesia. Jurnal Ilmu Komunikasi. Vol.9, No.1 : 30.

[6] Sunarya, Po Abas dan Lisa Anisah. 2018. Desain Komunikasi Visual Sebagai Media Informasi Pada Ditjen APTIKA Kementrian Komunikasi dan Informatika Jakarta. Tangerang : Universitas Raharja. Journal CERITA. ISSN : 2461-1417. Vol. 4, No. 1 : 79 dan 82.

[7] Raharjo, Hamdan Afif, dan Joni Dwi Pribadi 2017. Desain Spanduk Menggunakan CorelDraw Sebagai Media Promosi Untuk Meningkatkan Citra Pada SMP An-Nur Balulawang Malang. Malang: Politeknik Negri Malang. Jurnal Aplikasi Bisnis. ISSN:2407-3741. Vol.3, No.1:294.

[8] Maulani, Giandari. Siti Nur dan Yuri Mahbubi.2017. Desain Media Komunikasi Visual Berbentuk Tabloid Sebagai Sarana Promosi SMK Mandiri 2. Pontianak : STMIK Pontianak. Sisfotenika. ISSN : 2460-5344. Vol.7 No.1: 62. 